\title{
Elforgatott és ékezetes térképi megírások automatikus felismerése
}

\author{
Nemes Krisztián
}

DOI: https://doi.org/10.30921/GK.70.2018.4.2

\section{Kivonat}

Egy szkennelt térkép önmagában csak egy kép, amibôl az adatok kinyerése igen nehéz, azonban vektorizálás után már használhatóak egy új térkép alaptérképeként, különbözô adatbázisokat állíthatunk elô belôlük, amik már szúrhetôk, kereshetôk, az egyes térképi objektumok (pont, vonal, felületi elemek és megírások) könnyen és gyorsan módosíthatók a térkép felhasználási célja szerint. Eddigi munkámban a digitális térképen található szimbólumok automatikus felismerésével és vektorizálásával foglalkoztam. A kidolgozott eljárás teszteléséhez készítettem egy keretprogramot és egy hozzá tartozó adatbázist, amiben a térképi jelek adatai (magasság, szélesség, kifedett terület) tárolódnak. Jelen cikkemben pedig az eddig elért eredményeket alapul véve továbbléptem; az elforgatott és ékezetes karakterek felismerésének és vektorizálásának lehetôségét vizsgáltam. A cikk különbözô példákon keresztül mutatja be az eljárás múködését, mely egyszerúségének köszönhetôen akár ingyenes, nyílt forráskódú szoftverekbe is beépíthetô.

\section{Az eljárás múködése röviden}

Az eljárás elsố lépésként lecsökkenti a behívott térkép színmélységét, majd egy kis kernelablakkal végigfut a térképen, és különféle szúrôk (szín, méret) segítségével eltüntet minden felesleges elemet, kivéve az elôre definiált tû́réshatárt nem meghaladó méretú foltokat (1. ábra).

Ezután minden egyes - jelnek valószínúsíthetô - foltot megvizsgál méret és kitakaró területnagyság alapján. Először elmenti a méretkritériumoknak megfelelố folt képi koordinátáit, majd összeveti az adatbázisban tárolt összes jellel, méret, kiterjedés és alak szerint. Amelyiktől a legkevésbé tér el (azaz bizonyos százalék feletti értékben megegyezik vele), olyan jelnek feltételezi a foltot. A lefutás végén kapunk egy eredmény-adatbázist, amiben a felismert jelek találhatóak, képi koordinátákkal. Ezeket a képi koordinátákat valamennyi térinformatikai szoftver át tudja alakítani a megfelelố vetületi koordinátákká. Ezt az adatbázist aztán elmenthetjük Shape- vagy SVG-állományba, más térinformatikai szoftverekben való felhasználásra.

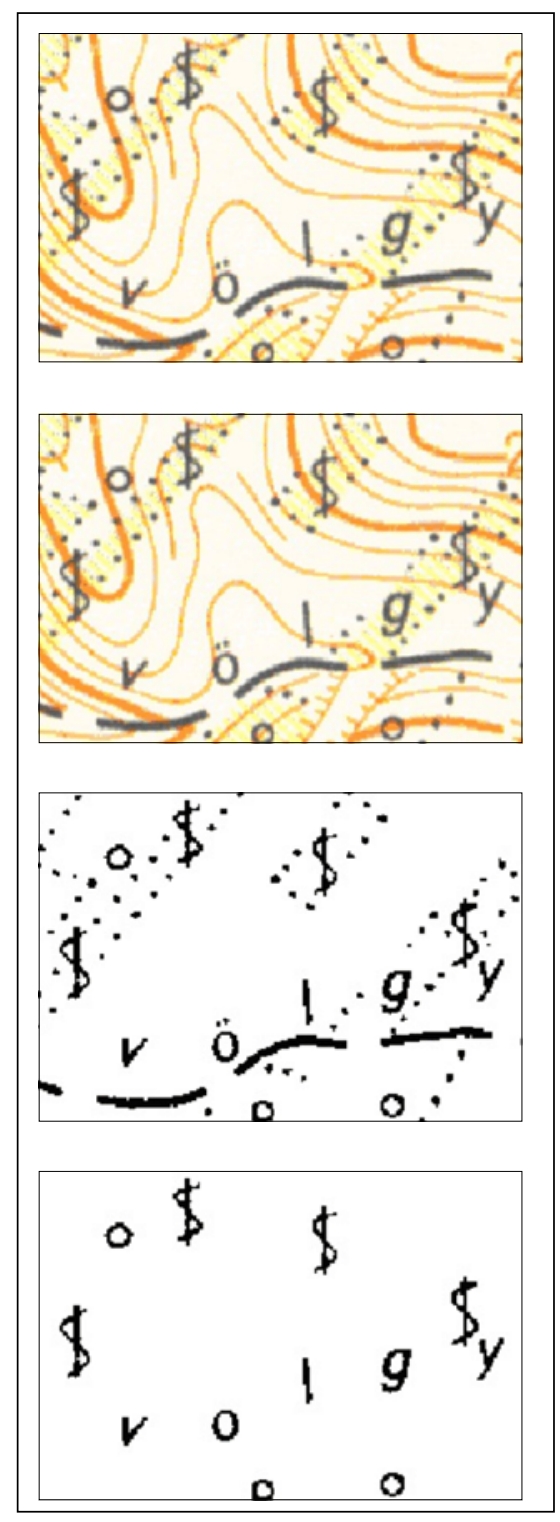

1. ábra. A jelek kinyerésének folyamata
Ugyan az eljárás alkalmas volt már betúk vektorizálására is, ugyanakkor még nem volt képes az ékezetes és bizonyos szögben elforgatott karakterek felismerésére.

\section{Elforgatott karakterek felismerése}

Az elforgatott karakterek talpra állítására már az elôzố munkámban is ismertettem egy lehetséges megoldást. Megfigyeltem, hogy ha egy karakter a négy fố iránytól (a talpára állított karakter; $90^{\circ}$-kal; $180^{\circ}$-kal és $270^{\circ}$-kal elforgatva) eltérô szögben áll, akkor az ôt szorosan körülölelô, úgynevezett befoglaló téglalap területe nagyobb, és minél inkább távolodunk a fó irányoktól, ez az érték annál jobban növekszik. Következésképp, ha egy adott értékkel forgatni kezdjük a karaktert, közben ez a terület csökken. Tehát pár iteráció után eljutunk valamelyik fố irányhoz. Ha közben a forgatás szögét eltároljuk, a végén megkapjuk, hogy hány fokkal kellett visszaforgatni a karaktert ahhoz, hogy e négy fó irány valamelyikét elérjük. A 2. ábra jól szemlélteti ezt.

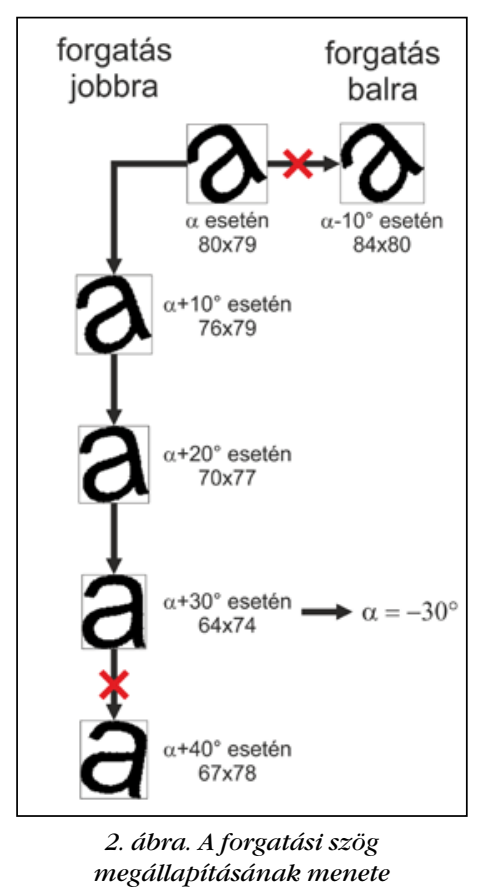




\begin{tabular}{|c|c|c|c|c|c|c|c|c|}
\hline & $\begin{array}{c}\text { Álló karakter } \\
\text { esetén }\end{array}$ & valószínúség & $\begin{array}{c}90^{\circ} \text {-kal } \\
\text { elforgatva }\end{array}$ & valószínúség & $\begin{array}{l}180^{\circ} \text {-kal } \\
\text { elforgatva }\end{array}$ & valószínúség & $\begin{array}{l}270^{\circ} \text {-kal } \\
\text { elforgatva }\end{array}$ & valószínúség \\
\hline \multirow{6}{*}{$\begin{array}{l}\text { A program } \\
\text { által } \\
\text { megtalált } \\
\text { karakter }\end{array}$} & 2 & $69,44 \%$ & 2 & $61,24 \%$ & 2 & $70,72 \%$ & 2 & $59,20 \%$ \\
\hline & 3 & $80,80 \%$ & 3 & $64,18 \%$ & 3 & $72,63 \%$ & 3 & $65,83 \%$ \\
\hline & $\mathrm{a}$ & $92,49 \%$ & $\mathrm{C}$ & $70,71 \%$ & $\mathrm{a}$ & $75,82 \%$ & $\mathrm{C}$ & $72,83 \%$ \\
\hline & & & $\mathrm{c}$ & $70,99 \%$ & $\mathrm{e}$ & $81,96 \%$ & $\mathrm{O}$ & $73,92 \%$ \\
\hline & & & $\mathrm{m}$ & $72,66 \%$ & & & Q & $74,01 \%$ \\
\hline & & & $\mathrm{O}$ & $74,33 \%$ & & & & \\
\hline
\end{tabular}

\begin{tabular}{|c|c|r|r|r|r|r|r|r|r|}
\hline $\begin{array}{c}\text { Jel kezdőbetújé- } \\
\text { nek ASCII kódja }\end{array}$ & $\begin{array}{c}\text { Jel kódja az } \\
\text { adatbázisban }\end{array}$ & $\begin{array}{c}\text { Jel } \\
\text { területe }\end{array}$ & $\begin{array}{c}\text { Alapkarakter } \\
\text { ASCII kódja }\end{array}$ & Szóalkotó? & $\begin{array}{c}\text { Forgatottság } \\
\left({ }^{\circ}\right)\end{array}$ & $\begin{array}{c}\text { Minimum } \\
\text { méret }\end{array}$ & $\begin{array}{c}\text { Maximum } \\
\text { méret }\end{array}$ & $\begin{array}{c}\text { Fix } \\
\text { méret? }\end{array}$ & $\begin{array}{c}\text { Felisme- } \\
\text { rési név }\end{array}$ \\
\hline 103 & $0,044 \# 0,773 \#$ & 27,077 & 32 & IGAZ & 0 & 11 & 19 & HAMIS & g \\
\hline 71 & $0,009 \# 0,462 \#$ & 19 & 32 & IGAZ & 0 & 35 & 40 & HAMIS & G \\
\hline 70 & $0 \# 0 \# 0,093 \# 0$, & 14,182 & 32 & HAMIS & 10 & 24 & 37 & IGAZ & Fa \\
\hline 102 & $0 \# 0,28 \# 0,689$ & 20 & 32 & IGAZ & 350 & 14 & 39 & HAMIS & f \\
\hline 70 & $1 \# 0,676 \# 0,66$ & 18 & 32 & IGAZ & 0 & 25 & 38 & HAMIS & F \\
\hline 233 & $0 \# 0 \# 0,027 \# 0$, & 21 & 101 & IGAZ & 0 & 24 & 39 & HAMIS & é \\
\hline
\end{tabular}

A felismerni kívánt karakter - egyelőre ismeretlen - elforgatottsági szöge legyen $\alpha$. Ha elkezdjük forgatni valamilyen irányba a karaktert, látható, hogy az ốt befoglaló téglalap mérete változik. Elsô lépésként megvizsgáljuk, balra vagy jobbra forgatva kezd-e csökkenni ez a terület. A 2. ábrán láthatjuk, hogy míg balra forgatva a karaktert, a terület nő, addig jobbra forgatva folyamatosan csökken - egy ideig. Ekkor már túlléptük valamelyik fố irányt, így egyet visszaforgatunk a karakteren. Megnézzük, hány fokkal forgattuk el $\alpha$-hoz képest, amire a legkisebb területet kaptuk. Ebból megkapjuk, hogy eredetileg hány fokkal volt elforgatva. Következô lépésként felismertetjük a karaktert a programmal. Ennek eredménye az 1. táblázatban látható. A program sikeresen felismerte az „a” betút, az elforgatás szöge pedig $30^{\circ}$ volt.

A 2. ábrán a visszaforgatás után épp a talpára állt a karakter.

Abban az esetben viszont, ha a fejjel lefelé irányt közelítjük, a sikeres felismerés fejjel lefelé adja a legnagyobb \%-os valószínúséget. Ekkor a elforgatottság szögét $\beta+\alpha$-val kapjuk, ahol $\beta$ az a szög, amelyik fó irányban a legnagyobb valószínúségú találatot adta vissza a program. Ezt szemlélteti a 3. ábra.

A $\beta$ szög értéke itt $180^{\circ}$, az $\alpha$ szögé pedig további $30^{\circ}$. A program tehát $210^{\circ}$-os elforgatottságot állapít meg.

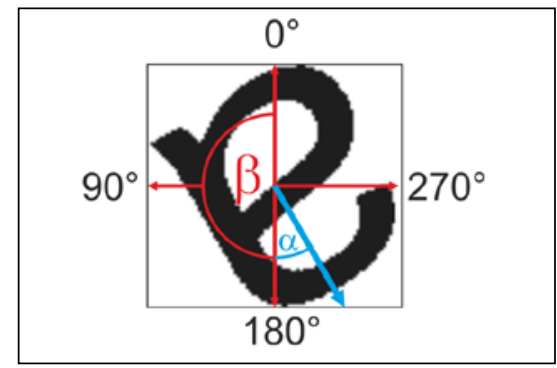

3. ábra. A forgatási szög alakulása fejjel lefelé álló karakter esetén

Ahhoz, hogy ezt a szöget is tárolni tudjuk, ki kellett egészíteni az adatbázist a forgatásiszög-attribútummal, továbbá a tanuláskor is figyelembe kellett venni, hogy eltároláskor nem biztos, hogy épp a talpára állított betú az, amelyik a legkisebb befoglaló téglalappal rendelkezik.

A 2. táblázat az adatbázis egy részét mutatja. Látható, hogy egy „Fa” nevú jel $10^{\circ}$-os, míg például az „f" betú $350^{\circ}$ os elforgatással került bele az adatbázisba. Felismeréskor ezt is figyelembe veszi a program a végleges elforgatottsági szög kiszámításánál.

\section{Ékezetes betúk felismerése}

Az ékezetes betûk felismerésére szintén egy új attribútum került bevezetésre az adatbázisban. Ez az attribútum tárolja, hogy az adott betûhöz tartozik-e egy ékezet nélküli, úgynevezett alapkarakter (pl. á $\Rightarrow$ a, é $\Rightarrow$ e). Ez látható a 2. táblázatban is, az
„Alapkarakter ACSII-kódja” oszlopban. Például az „é” betú alapja a 101es ASCII-kódú „e” betû.

A fentebb említett eljárás csak az alapkaraktereket ismeri fel. Mielôtt azonban a program eltárolná az eredmény-adatbázisba a felismert betût, még megvizsgálja, lehet-e ez a betú alapja egy ékezetes karakternek, azaz van-e olyan elem az adatbázisban, ahol az alapkarakter ASCII-kódja megegyezik ennek a betûnek az ASCII-kódjával. Ha a lekérdezés ad vissza találatot, akkor a program az alapkarakter méretének és koordinátáinak ismeretében kiemeli azt az eredeti képról a tágabb környezetével együtt, ahol ékezetek lehetnek.

Vegyük példának a következó térképkivágatot (4. ábra). Az alkalmazott szűrốk segítségével csak a lehetséges karakterek maradnak a térképen. A „Fưz-halom” megírás egyetlen ékezetes karaktere egy „ű” betú. A program először csak annak alapját, egy „u” betút ismer fel (3. táblázat).

Látható, hogy álló karakter feltételezése mellett találta meg a program az „u” betût (80,77\%). A hozzá legközelebbi találat az „n” betú volt $(79,87 \%)$, amit a folt $180^{\circ}$-os elforgatottságának feltételezése esetén adott a program.

Következő lépésként megvizsgálja, hogy az adatbázisban van-e olyan karakter, aminek „u” betú az alapja. Ez adatbázisonként - melyet 


\begin{tabular}{|c|c|r|r|r|r|r|r|r|}
\hline & $\begin{array}{c}\text { 3. táblázat } \\
\text { élló karakter } \\
\text { esetén }\end{array}$ & valószínúség & $\begin{array}{c}90^{\circ} \text {-kal } \\
\text { elforgatva }\end{array}$ & valószínúség & $\begin{array}{c}180^{\circ} \text {-kal } \\
\text { elforgatva }\end{array}$ & valószínúség & $\begin{array}{c}270^{\circ} \text {-kal } \\
\text { elforgatva }\end{array}$ & \begin{tabular}{c} 
valószínúség \\
\hline
\end{tabular} \\
\cline { 2 - 10 } & 0 & $67,62 \%$ & 0 & $61,47 \%$ & 0 & $65,47 \%$ & 0 & $68,46 \%$ \\
\hline \multirow{3}{*}{$\begin{array}{c}\text { A program } \\
\text { által megta- } \\
\text { lált karakter }\end{array}$} & $\mathrm{c}$ & $67,62 \%$ & 2 & $67,01 \%$ & $\mathrm{a}$ & $65,71 \%$ & 3 & $74,72 \%$ \\
\cline { 2 - 10 } & $\mathrm{d}$ & $68,28 \%$ & $\mathrm{c}$ & $72,98 \%$ & $\mathrm{~b}$ & $69,79 \%$ & & \\
\cline { 2 - 11 } & $\mathrm{u}$ & $73,50 \%$ & & & $\mathrm{n}$ & $79,87 \%$ & & \\
\hline
\end{tabular}

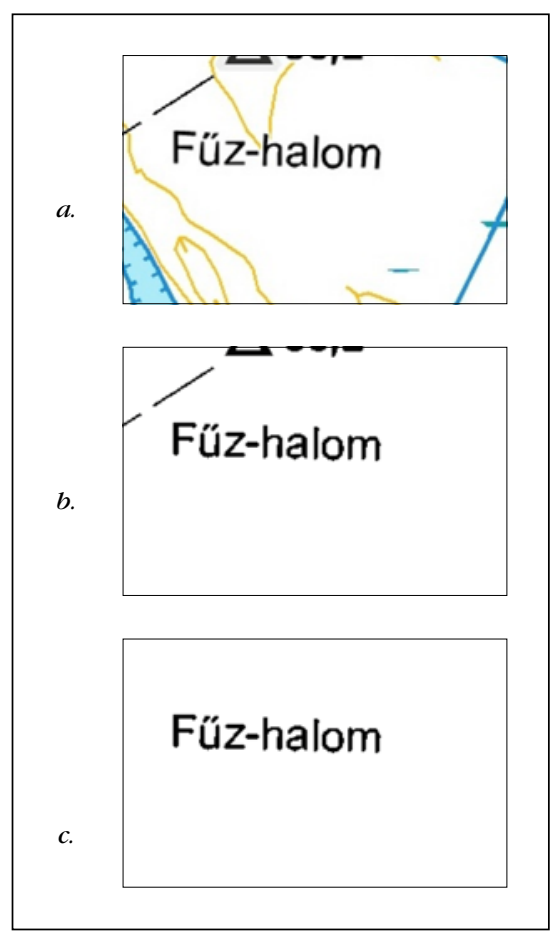

4. ábra. A felesleges tartalom eltávolitása a kivágatból különbözố szürôk segítségével

4. táblázat

\begin{tabular}{|c|c|r|}
\hline & $\begin{array}{c}\text { Felismert } \\
\text { karakter }\end{array}$ & valószínúség \\
\hline A program & $\mathrm{u}$ & $75,45 \%$ \\
\cline { 2 - 3 } $\begin{array}{c}\text { által megta- } \\
\text { lált „u” alapú } \\
\text { karakter }\end{array}$ & ú & $79,05 \%$ \\
\cline { 2 - 3 } & $\ddot{\mathrm{u}}$ & $\mathbf{8 2 , 2 0 \%}$ \\
\cline { 2 - 3 } & \multicolumn{2}{|c}{} \\
\hline
\end{tabular}

a felhasználó állít elô - eltérô, több találat is lehetséges attól függóen, milyen karaktereket tanítottunk meg a programnak.

Az ebben az esetben használt adatbázisnál a programnak az [u, ú, ü, û] listából kell kiválasztania a megfelelôt, azaz melyik hasonlít leginkább a foltra, amelynek „u” az alapja.

Ennek alakulását a 4. táblázat mutatja. Látható, hogy „ü” betú nem sokkal $(82,20 \%)$, de alul maradt az „û"-vel szemben $(83,64 \%)$.

Egy másik példával szemléltetve, az 5. a. ábrán látható „Hosszú-árok”

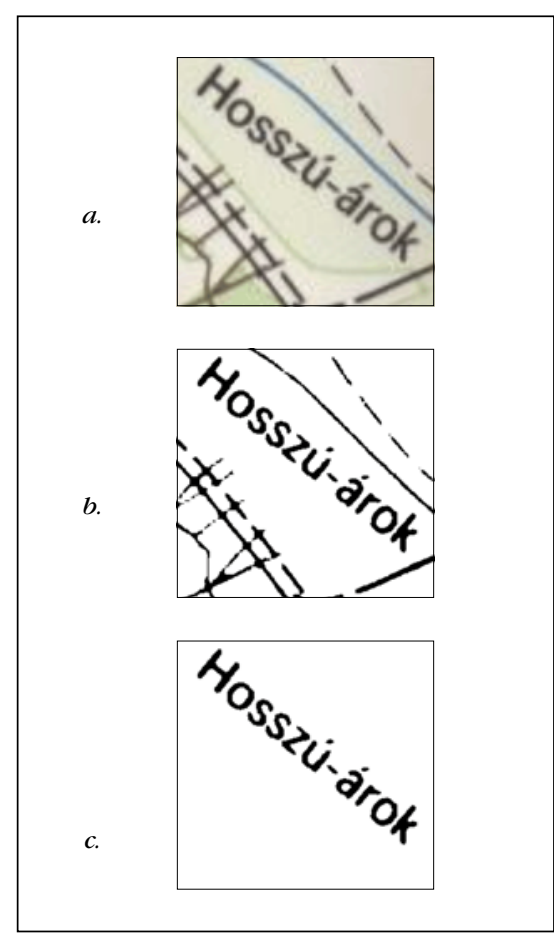

5. ábra. Példa egy másik kivágaton keresztül

megírást emeli ki a program a térképrốl. Ehhez redukálja a kép színeit, majd a számunkra megfelelót (fekete) kiválasztjuk, így a többivel nem kell foglalkoznunk (5. b. ábra). Újabb szúrök használatával megszabadítja a kivágatot a túl rövid/kicsi, vagy épp túl hosszú/nagy foltoktól (5. c. ábra).

Majd a karakterfelismerési eljárás következik. A program elôször megtalálja az alapkaraktereket („u” és „a” betű), majd - ha az adatbázisban található olyan karakter, aminek ezek a betûk az alapjai - ismerve azok elforgatottsági szögeit -, visszaforgatja ôket álló helyzetbe a tágabb környezetükkel együtt (6. b. ábra). Most újabb szúrố funkciók futnak le a képen. Ezek célja, hogy minden felesleges pixelt eltüntessenek a képról, ami nem része az alapkarakternek, és nem az ékezet(ek) feltételezett helyén van (6. c. ábra), majd lecsökkenti a kép

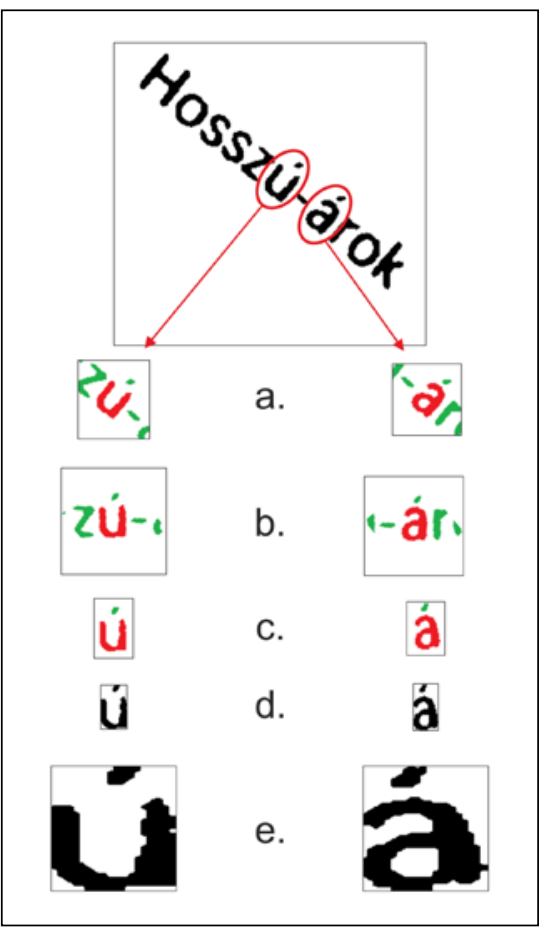

6. ábra. Ékezetes karakterek felismerésének menete

5. táblázat

\begin{tabular}{|c|c|r|}
\hline \multirow{2}{*}{ Alapkarakter } & $\begin{array}{c}\text { Felismert } \\
\text { karakter }\end{array}$ & valószínűség \\
\hline \multirow{2}{*}{ u } & u & $66,07 \%$ \\
\cline { 2 - 3 } & ú & $74,70 \%$ \\
\hline \multirow{2}{*}{ a } & a & $59,72 \%$ \\
\cline { 2 - 3 } & á & $78,49 \%$ \\
\hline
\end{tabular}

méretét, és áttranszformálja a felismeréshez szükséges méretû képpé (6. d. és e. ábra).

A felismeréshez az adatbázisból már csak azokat az elemeket veszi alapul a program, melyek alapkaraktere $a z$ „u” és az „a” betû, illetve saját magukat. Így csökkenthetô a téves felismerés valószínúsége. Ennek alapján - ahogy az 5. táblázatban is látható a két betûre csak két-két lehetôség adódott, és az ékezetes karakterekre nagyobb valószínúséggel hasonlítottak a foltok, a program helyesen ismerte fel ôket. 


\section{Betúk összekapcsolása szavakká}

A karakterek visszaforgatásával és az ékezetes betűk felismerésével már lehetôség nyílt arra, hogy az egyes betúket össze lehessen kapcsolni szavakká. Ehhez felhasználtam azt, hogy a megírást alkotó karakterek általában egy irányba vannak elforgatva (7. ábra).

Miután az összes lehetséges (a térképen található) karaktert felismerte a program, az elforgatottsági szögekbôl listát alkot. A 8. ábrán látható „BUDAPEST” megírás minden karaktere egy bizonyos $\beta+\alpha$ szöggel van elforgatva. A program kiválogatja az ilyen szöggel elforgatott karaktereket a felismert betúk közül, majd megvizsgálja azok egymáshoz való viszonyát bizonyos paraméterek alapján (9. ábra).

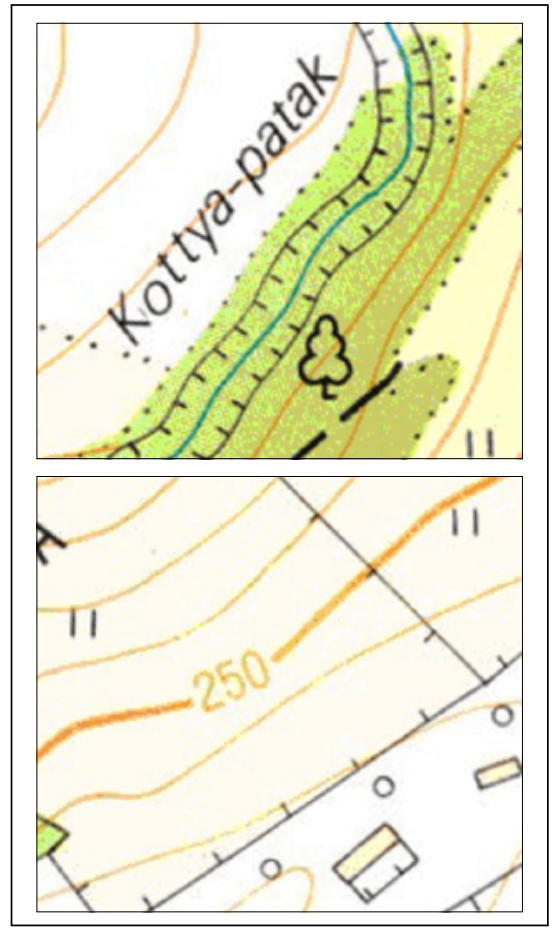

7. ábra. Azonos szögben elforgatott valószínúsíthetốn kapcsolódó karakterek

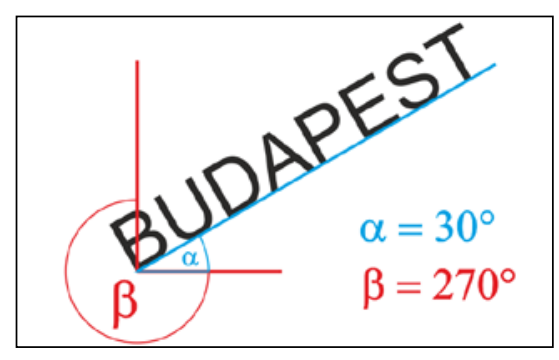

8. ábra. Példa az

egy megírást alkotó karakterekre
Ezek a paraméterek a következők:

- aktuális betû́ („B”) szélessége (w)

- az aktuális betú („B”) magassága (h)

- a szomszédosnak feltételezett betú („U”) és az aktuális betû középpontkoordinátájának különbsége $(\Delta x$, $\Delta \mathrm{y})$

- a két betû́ középpontjának távolsága $(\Delta \mathrm{t})$

- a két betú középpontját összekötő szakasznak $(\Delta \mathrm{t})$ a vízszintessel bezárt szöge $(\chi)$

Felhasználjuk, hogy $\Delta x^{2}+\Delta y^{2}=\Delta t^{2}$, amiből megkapjuk a $\Delta$ t értékét, majd ebből a $\sin (\chi)=\Delta y / \Delta t$ összefüggés segítségével megkapjuk a $\chi$ szöget. Annak a feltétele, hogy a 9. ábrán látható „B”-t és „U”-t össze tudja kapcsolni a program, a következő:

- $\Delta$ t értéke nem lehet nagyobb, mint $1,5 \times(\mathrm{w}+\mathrm{h}) / 2$, hiszen csak bizonyos távolságon belüli karaktereket kapcsolhatunk össze,

- illetve teljesülnie kell annak, hogy $|\chi-\alpha|<10^{\circ}$, mert bár nagyjából egy irányba vannak elforgatva, és közel is vannak egymáshoz, azért az is elképzelhetô, hogy az egyik a másik felett van.

Ugyan látszólag az $\alpha$ és a $\chi$ szög értéke megegyezik, ez az érték a két egymást követô betú méretkülönbsége és elhelyezkedése miatt eltérhet. A betúk összekapcsolásánál figyelembe kell vennünk azt is, hogy a következô betû́ az elôzó elé, vagy mögé kell hogy kerüljön. Ez a már összekapcsolt betűk és a következó betû́ koordinátájának különbségéból, illetve a megírás irányultságából állapítható meg.

A 10. ábrán látható - már összekapcsolt - „un” megíráshoz adná hozzá a program a „D” és az ,a” betúket. Az „un” megírás középpontja $\mathrm{P}_{0}$, a „D” betúé $\mathrm{P}_{1}$, míg az „a” betúé $P_{2}$. A $\beta+\alpha$ irányultsága és a $\Delta \mathrm{x}_{1}$ és $\Delta \mathrm{y}_{1}$ koordináta-különbsége

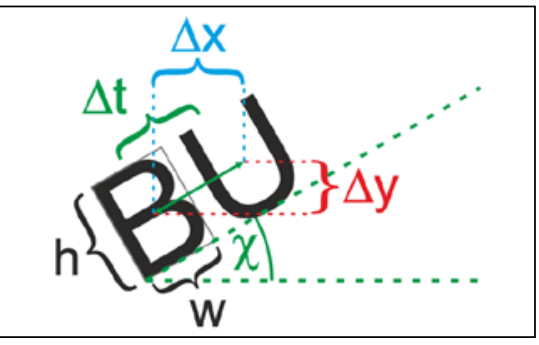

9. ábra. Karakterek közötti kapcsolat vizsgálata miatt a „D” betú az „un” megírás elé, míg a $\Delta x_{2}$ és $\Delta y_{2}$ miatt az „a” betú a megírás végére kerül. Az így keletkezett „Duna” megírás új középpontját a program elóbb a $\mathrm{P}_{0}$ és $\mathrm{P}_{1}$ pont koordinátáinak átlagából, majd az így kapott új középpont és a $\mathrm{P}_{2}$ pont koordinátáinak átlagából számolja. Az itt felhasznált betûket pedig kiveszi a felismert betûk listájából, hiszen több megírásnak már nem képezhetik részét.

\section{Felhasználási lehetôségek}

A végeredmény tehát egy digitalizált térképból kinyert vektoros adatbázis, amiben két tábla található. Az elsóben vannak felsorolva a felismert karakterek és szimbólumok, egyenként. Ezt mutatja a 6. táblázat. Ebben látható:

- felismert karakter vagy szimbólum,

- hány százalékos valószínúséggel találta meg a jó karaktert a program,

- karakter képi XY koordinátája,

- karakter szélessége és magassága pixelben,

- elforgatottsági szöge a térképen,

- adott karakter szóalkotó karakter-e,

- fix méretben található-e a térképen (pl. bizonyos térképi szimbólumok),

- egy adott irányban állhat-e a térképen (pl. alappont-jelek a térképen),

- és hogy a program már felhasználta-e a megírások összekapcsolásakor

A második táblázatban pedig az összekapcsolt betúkből keletkezett megírások találhatóak (7. táblázat).

Ez tárolja:

- magát a megírást,

- a megírás elforgatottsági szögét,

- a megírás XY koordinátáját a képen,

- és a megírás színét.

Ezeket az adatbázisokat exportálhatjuk Shape- vagy Scalable Vector Graphics

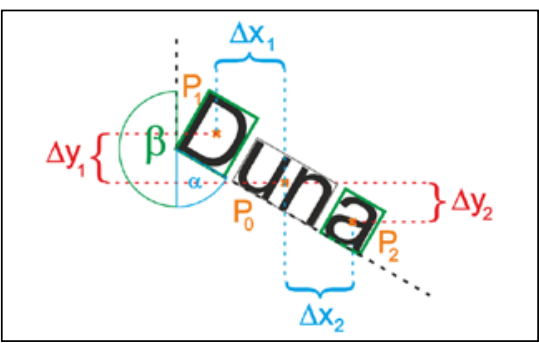

10. ábra. Új betúk kapcsolásának módja felismert megíráshoz 


\begin{tabular}{|c|r|r|r|r|r|r|r|c|c|c|}
\hline Karakter & Valószínúség (\%) & \multicolumn{1}{|c|}{$\mathrm{X}$} & \multicolumn{1}{|c|}{$\mathrm{Y}$} & Szélesség & Magasság & Forgatási szög $\left(^{\circ}\right)$ & Szóalkotó? & $\begin{array}{c}\text { Fix } \\
\text { méret? }\end{array}$ & $\begin{array}{c}\text { Fix } \\
\text { irány? }\end{array}$ & Felhasznált? \\
\hline P & 84 & 62 & 59 & 21 & 28 & 0 & igen & nem & nem & igen \\
\hline é & 88 & 85 & 62 & 18 & 21 & 0 & igen & nem & nem & igen \\
\hline c & 84 & 106 & 62 & 19 & 21 & 0 & igen & nem & nem & igen \\
\hline s & 83 & 127 & 62 & 18 & 21 & 0 & igen & nem & nem & igen \\
\hline S & 91 & 156 & 182 & 22 & 28 & 0 & igen & nem & nem & igen \\
\hline d & 84 & 263 & 182 & 20 & 28 & 0 & igen & nem & nem & igen \\
\hline z & 83 & 178 & 186 & 17 & 21 & 0 & igen & nem & nem & igen \\
\hline e & 83 & 197 & 186 & 18 & 21 & 0 & igen & nem & nem & igen \\
\hline g & 81 & 219 & 189 & 20 & 28 & 0 & igen & nem & nem & igen \\
\hline e & 83 & 241 & 186 & 18 & 21 & 0 & igen & nem & nem & igen \\
\hline
\end{tabular}

7. táblázat

\begin{tabular}{|c|r|c|c|c|}
\hline Megírás & $\begin{array}{c}\text { Forgatási } \\
\text { szög }\left(^{\circ}\right)\end{array}$ & $\mathrm{X}$ & $\mathrm{Y}$ & Szín \\
\hline Pécs & 0 & 94 & 60 & fekete \\
\hline Szeged & 0 & 210 & 182 & fekete \\
\hline
\end{tabular}

(SVG) fájlba, így más térinformatikai szoftverben is megnyithatók és felhasználhatók. Például a megírások színeibôl könnyen csoportokat alkothatunk: minden, ami kékkel lett megírva, az valószínúleg vízrajzi név; ami barnával, az domborzathoz köthetô megírás. A felismert szimbólumok pedig könynyen átalakíthatóak, hiszen szúrhetôk és kategorizálhatók.

Természetesen az eljárás nem csak térképi karaktereket ismer fel. Felhasználható egyéb, szkennelt dokumentum szövegeinek felismerésére és vektorizálására is.

\section{Irodalom}

Araokar, S. 2005. Visual Character Recognition using Artificial Neural Networks, https://arxiv.org/ftp/cs/papers/0505/0505 016.pdf

Chiang, Y. - Knoblock, C. A. 2015. Recognizing text in raster maps, Journal Geoinformatica, DOI: https://doi.org/10.1007/s10707-0140203-9

https:/pdfs.semanticscholar.org/4287/54329 311 fada930309dee2f68413075edcb3.pdf

Field, J. L. 2014. Improving Text Recognition In Images Of Natural Scenes, https://web. cs.umass.edu/publication/docs/2014/ UM-CS-PhD-2014-003.pdf
Iqbal, Asif - Musa, A. B. M. - Tahsin, Anindya - Sattar, Md. Abdus - Islam, Md. Monirul Murase, Kazuyuki 2008. A Novel Algorithm for Translation, Rotation and Scale Invariant Character Recognition, SCIS \& ISIS https:// www.cs.uic.edu/pub/Bits/Musa/musa-scisisis08.pdf

Jawahar, C.V. - Alahari, K.- Mishra, A. 2012 Top-Down and Bottom-up Cues for Scene Text Recognition, Computer Vision and Pattern Recognition (CVPR), IEEE Conference, DOI: https://doi.org/10.1109/ CVPR.2012.6247990

Nemes, K. 2017. Térképen található karakterek és szimbólumok felismerése és vektorizálása, Geodézia és Kartográfia, 69. évf. 2. sz. pp. 29-33

Szabó, Cs. 2007. Kézzel írt szövegek feldolgozása tanuló algoritmusokkal, https://dea.lib.unideb.hu/dea/bitstream/ handle/2437/2362/Diplomamunka.pdf

Velázquez, A. - Levachkine, S. 2003. Text/ Graphics Separation and Recognition in Raster-scanned Color Cartographic Maps Graphics Recognition. Recent Advances and Perspectives pp. 63-74., DOI: https://doi. org/10.1007/978-3-540-25977-0 6

\section{Summary}

Nowadays, maps are mostly stored in digital form. The next step is to vectorize them. Vectorizing maps manually can be a long process; however, we can utilize the computing speed of computers. Computer automation is a developing area which can be used to vectorize maps. In this work, I developed a very simple method to automatically recognize rotated characters and vectorize them, even when they are accented. It is based on a database, in which all the characters and symbols are stored. The method compares the characters on the map with those stored in the database, and returns the database character with the highest match. The result of the process is an output database, where all the recognized characters are stored with image coordinates and rotation angles. The method can connect characters which are close enough to each other according to certain parameters, and can return the word formed by these connected characters.

Kulcsszavak: automatikus betúfelismerés, szövegfelismerés, automatikus térkép-vektorizálás

Keywords: character recognition, text recognition, automatic vectorising maps

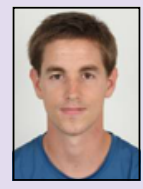

Nemes

Krisztián doktorandusz

ELTE TTK Földtudományi Doktori Iskola nekpaat@gmail.com 